Nevada

Environmental

Restoration

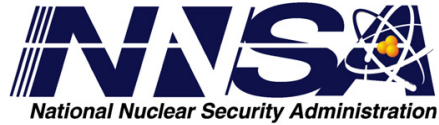

Project

Addendum to the Corrective Action

Decision Document/Closure Report for

Corrective Action Unit 321: Area 22

Weather Station Fuel Storage

Nevada Test Site, Nevada

Controlled Copy No.:

Revision No.: 0

October 2008

Approved for public release; further dissemination unlimited.

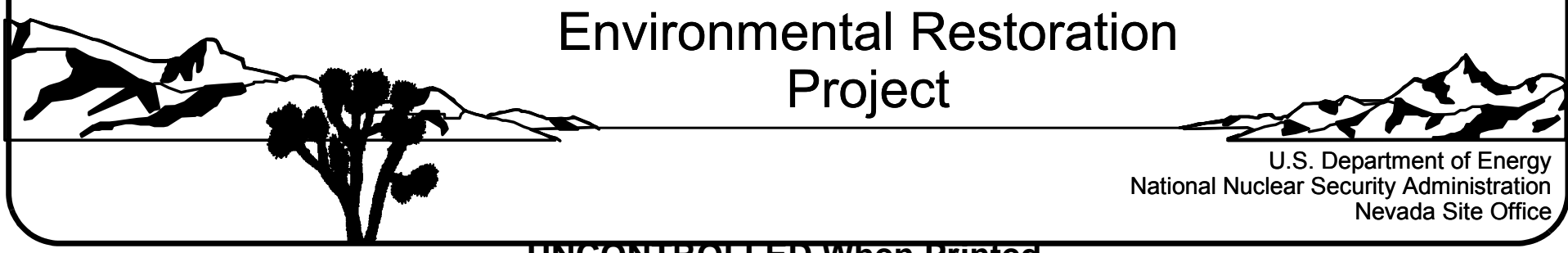


Available for public sale, in paper, from:

U.S. Department of Commerce

National Technical Information Service

5285 Port Royal Road

Springfield, VA 22161

Phone: 800.553 .6847

Fax: 703.605.6900

Email: orders@ntis.gov

Online ordering: http://www.ntis.gov/ordering.htm

Available electronically at $\underline{h t p: / / w w w . o s t i . g o v / b r i d g e ~}$

Available for a processing fee to U.S. Department of Energy and its contractors, in paper, from:

U.S. Department of Energy

Office of Scientific and Technical Information

P.O. Box 62

Oak Ridge, TN 37831-0062

Phone: 865.576 .8401

Fax: 865.576.5728

Email: reports@adonis.osti.gov

Reference herein to any specific commercial product, process, or service by trade name, trademark, manufacturer, or otherwise, does not necessarily constitute or imply its endorsement, recommendation, or favoring by the United States Government or any agency thereof or its contractors or subcontractors. 


\title{
ADDENDUM TO THE CORRECTIVE ACTION DECISION DOCUMENT/CLOSURE REPORT FOR CORRECTIVE ACTION UNIT 321: AREA 22 WEATHER STATION FUEL STORAGE NEVADA TEST SITE, NEVADA
}

\author{
U.S. Department of Energy \\ National Nuclear Security Administration \\ Nevada Site Office \\ Las Vegas, Nevada
}

Controlled Copy No.:

Revision No.: 0

October 2008

Approved for public release; further dissemination unlimited. 


\section{Addendum to the Corrective Action Decision Document / Closure Report for Removal of the Use Restriction}

This document constitutes an addendum to the August 2001, Corrective Action Decision Document / Closure Report for Corrective Action Unit 321: Area 22 Weather Station Fuel Storage as described in the document Recommendations and Justifications for Modifications for Use Restrictions Established under the U.S. Department of Energy, National Nuclear Security Administration Nevada Site Office Federal Facility Agreement and Consent Order (UR Modification document) dated February 2008. The UR Modification document was approved by NDEP on February 26, 2008. The approval of the UR Modification document constituted approval of each of the recommended UR modifications. In conformance with the UR Modification document, this addendum consists of:

- This cover page that refers the reader to the UR Modification document for additional information

- The cover and signature pages of the UR Modification document

- The NDEP approval letter

- The corresponding section of the UR Modification document

This addendum provides the documentation justifying the cancellation of the UR for CAS 22-99-05, Fuel Storage Area. This UR was established as part of a Federal Facility Agreement and Consent Order (FFACO) corrective action and is based on the presence of contaminants at concentrations greater than the action levels established at the time of the initial investigation (FFACO, 1996; as amended August 2006).

Since this UR was established, practices and procedures relating to the implementation of risk-based corrective actions (RBCA) have changed. Therefore, this UR was re-evaluated against the current RBCA criteria as defined in the Industrial Sites Project Establishment of Final Action Levels (NNSA/NSO, 2006c). This re-evaluation consisted of comparing the original data (used to define the need for the UR) to risk-based final action levels (FALs) developed using the current Industrial Sites RBCA process.

The re-evaluation resulted in a recommendation to remove the UR because contamination is not present at the site above the risk-based FALs. Requirements for inspecting and maintaining this UR will be canceled, and the postings and signage at this site will be removed. Fencing and posting may be present at this site that are unrelated to the FFACO UR such as for radiological control purposes as required by the $N V / Y M P$ Radiological Control Manual (NNSA/NSO, 2004f). This modification will not affect or modify any non-FFACO requirements for fencing, posting, or monitoring at this site. 
Nevada

Environmental

Restoration

Project

Recommendations and Justifications for Modifications for Use Restrictions Established under the U.S. Department of Energy, National Nuclear Security Administration Nevada Site Office

Federal Facility Agreement and Consent Order

Controlled Copy No.:

Revision No.: 0

February 2008

Approved for public release; further dissemination unlimited.

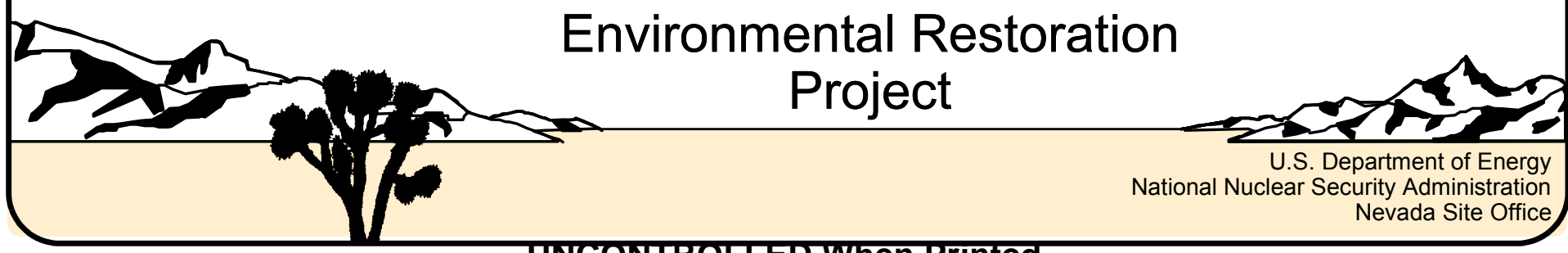


Recommendations and Justifications for Modifications for Use Restrictions Established under the U.S. Department of Energy, National Nuclear Security Administration Nevada Site Office Federal Facility Agreement and Consent Order

Approved by: /s/ Kevin J. Cabble

Date: $02 / 05 / 2008$

Kevin J. Cabble

Federal Sub-Project Director

Industrial Sites Sub-Project

Approved by:

/s/ John B. Jones

Date: $02 / 04 / 2008$

John B. Jones

Acting Federal Project Director

Environmental Restoration Project 
February 26, 2008

John B. Jones

Acting Federal Project Director

Environmental Restoration Project

National Nuclear Security Administration

Nevada Site Office

P. O. Box 98518

Las Vegas, NV 89193-8518

RE: Approval of Recommendations and Justifications for Modifications for Use Restrictions

Established under the U.S. Department of Energy, National Nuclear Security Administration, Nevada Site Office Federal Facility Agreement and Consent Order

Dear Mr. Jones:

The Nevada Division of Environmental Protection, Bureau of Federal Facilities (NDEP) staff has received and reviewed the February 2008 final report for Recommendations and Justifications for Modifications for Use Restrictions Established under the U.S. Department of Energy, National Nuclear Security Administration, Nevada Site Office. The NDEP approves the requested changes to the previously agreed upon use restrictions for those Corrective Action Sites (CASs) as described in the report.

Address any questions regarding this matter to either Ted Zaferatos at (702) 486-2850, ext. 234 , or me at (702) 486-2850, ext. 231.

Sincerely

\section{/s/ Tim Murphy}

\section{T.H. Murphy}

Chief

Bureau of Federal Facilities

$\mathrm{TZ}$

cc: $\quad$ E.F. DiSanza, WMP, NNSA/NSO

FFACO Group, PSG, NNSAINSO, Las Vegas, NV

David C. Loewer, DTRAVCXT1, M/S 645, Mercury, NV

W.R. Griffin, SNJV/DTRA, M/S 645, Mercury, NV

T.A. Thiele, NSTec, Las Vegas, NV

R.F. Boehlecke, SNJV, Las Vegas, NV

K. J. Cabble, ERP, NNSANSO, Las Vegas, NV

John Wong. Jeff MacDougall, Dennis Nicodemus, NDEP Las Vegas, NV 


\subsection{CAU 321, CAS 22-99-05 - Fuel Storage Area}

\subsection{CAS Description}

Corrective Action Site 22-99-05 is the only CAS within CAU 321, located in Area 22 of the NTS. The Fuel Storage Area was used to store fuel and other petroleum products necessary for motorized operations at the historic Camp Desert Rock facility, which was operational from 1951 to 1958. The Fuel Storage Area was dismantled after 1958 (NNSA/NV, 2001b).

The Fuel Storage Area was identified as a potential oil spill site. A 1955 aerial photograph shows two rectangular tanks and other items stored within the bermed Fuel Storage Area. The site has one relatively small area where slightly discolored soil has been observed. Otherwise, there is no visible staining, odor, or vegetative stress observed within the Fuel Storage Area (NNSA/NV, 2001b).

\subsection{Current Use Restriction Description}

The future use of any land related to this UR, as defined by the 150-square-foot $\left(\mathrm{ft}^{2}\right)$ area, located in the southeast corner of CAU 321, is restricted from any DOE or Air Force activity that may alter or modify the containment control, as approved by the state and identified in the CAU CR or other CAU documentation, unless appropriate concurrence is obtained in advance. There are no monitoring requirements associated with this UR (NNSA/NV, 2001b).

\subsection{Basis for Current Use Restriction}

Samples were analyzed for VOCs, SVOCs, TPH-gasoline, TPH-diesel, and total lead. Samples analyzed for TPH (DRO) at 11 to $12 \mathrm{ft}$ below ground surface (bgs), and 16 to $17 \mathrm{ft} \mathrm{bgs} \mathrm{from}$ sample location 32100E during the January/February 2001 investigation, had concentrations of $220 \mathrm{mg} / \mathrm{kg}$ and $170 \mathrm{mg} / \mathrm{kg}$, respectively. These concentrations exceeded the PAL of $100 \mathrm{mg} / \mathrm{kg}$. No VOCs or SVOCs were detected above PALs. No radiological analyses were conducted because all the field survey results were within background levels. No other contaminants were identified above PALs at the site (NNSA/NV, 2001b).

Table 8-1 contains analytical results of all COCs at CAS 22-99-05 that are the basis for the current UR. The sample matrix for all samples is soil. 
Table 8-1

Sample Results for COCs at CAS 22-99-05

Used To Establish Current Use Restriction

\begin{tabular}{|c|c|c|c|}
\hline \multirow[b]{2}{*}{ Investigation } & \multirow[b]{2}{*}{ Sample ID } & \multirow{2}{*}{$\begin{array}{c}\text { Depth } \\
\text { (ft bgs) }\end{array}$} & \multirow{2}{*}{$\begin{array}{c}\text { TPH (DRO) } \\
\text { PAL } \\
100 \mathrm{mg} / \mathrm{kg}\end{array}$} \\
\hline & & & \\
\hline \multirow{2}{*}{ January/February 2001} & $32100 E 11$ & $11-12$ & 220 \\
\hline & $32100 E 16$ & $16-17$ & 170 \\
\hline $\begin{array}{l}\text { bgs = Below ground surface } \\
\text { DRO = Diesel-range organics } \\
\mathrm{ft}=\text { Foot } \\
\text { ID = Identification }\end{array}$ & \multicolumn{3}{|c|}{$\begin{array}{l}\mathrm{mg} / \mathrm{kg}=\text { Milligrams per kilogram } \\
\mathrm{PAL}=\text { Preliminary action level } \\
\mathrm{TPH}=\text { Total petroleum hydrocarbons }\end{array}$} \\
\hline
\end{tabular}

\subsection{Basis for Use Restriction Modification}

The revised FALs associated with the TPH contamination were established based on the PALs of hazardous constituents of TPH diesel as described in Section 2.2.2. Hazardous constituents of TPH diesel were not detected in any of the samples at concentrations greater than their respective PALs (NNSA/NV, 2001b). Therefore, no contaminants are present at this site in concentrations exceeding the revised FALs, and all revised FALs were established at the PAL concentrations.

\subsection{Proposed Modification}

Remove the FFACO UR and associated fencing and postings from this CAS. 


\section{References}

FFACO, see Federal Facility Agreement and Consent Order.

Federal Facility Agreement and Consent Order. 1996 (as amended). Agreed to by the State of Nevada; U.S. Department of Energy, Environmental Management; U.S. Department of Defense; and U.S. Department of Energy, Legacy Management.

NNSA/NSO, see U.S. Department of Energy, National Nuclear Security Administration Nevada Site Office.

NNSA/NV, see U.S. Department of Energy, National Nuclear Security Administration Nevada Operations Office.

U.S. Department of Energy, National Nuclear Security Administration Nevada Operations Office. 2001b. Corrective Action Decision Document/Closure Report for Corrective Action Unit 321: Area 22 Weather Station Fuel Storage, Nevada Test Site, Nevada, Rev. 1, DOE/NV--726. August. Las Vegas, NV.

U.S. Department of Energy, National Nuclear Security Administration Nevada Site Office. 2004f. NV/YMP Radiological Control Manual, DOE/NV--11718-079, Rev. 5. Prepared by Bechtel Nevada. Las Vegas, NV.

U.S. Department of Energy, National Nuclear Security Administration Nevada Site Office. 2006c. Industrial Sites Project Establishment of Final Action Levels, Rev. 0, DOE/NV--1107. Las Vegas, NV. 


\title{
Library Distribution List
}

\author{
$\underline{\text { Copies }}$ \\ U.S. Department of Energy \\ 1 (Uncontrolled, electronic copy) \\ National Nuclear Security Administration \\ Nevada Site Office \\ Technical Library \\ P.O. Box 98518, M/S 505 \\ Las Vegas, NV 89193-8518 \\ U.S. Department of Energy \\ Office of Scientific and Technical Information \\ 1 (Uncontrolled, electronic copy) \\ P.O. Box 62 \\ Oak Ridge, TN 37831-0062 \\ Southern Nevada Public Reading Facility \\ 2 (Uncontrolled, electronic copies) \\ c/o Nuclear Testing Archive \\ P.O. Box 98521, M/S 400 \\ Las Vegas, NV 89193-8521 \\ Manager, Northern Nevada FFACO \\ 1 (Uncontrolled, electronic copy) \\ Public Reading Facility \\ c/o Nevada State Library \& Archives \\ 100 N Stewart Street \\ Carson City, NV 89701-4285
}

